\title{
Strategi Optimalisasi Budidaya Abalon (Haliotis asinina) Di Pulau Lombok Menggunakan Matriks Leslie
}

\author{
Mamika Ujianita Romdhini, Marliadi Susanto \\ Program Studi Matematika FMIPA Universitas Mataram \\ email :mamika_ur@yahoo.com
}

\begin{abstract}
Abstrak
Suatu studi tentang strategi optimalisasi budidaya abalon di Pulau Lombok menggunakan matriks Leslie telah dilakukan. Abalon (Haliotis asinina) merupakan salah satu etnofauna andalan NTB dan nasional sebagai komoditas perairan laut untuk ekspor. Penurunan produksi abalon yang disertai dengan mahalnya harga jual dan tingginya permintaan dunia tehadap abalon menjadi peluang sekaligus tantangan bagi pengembangan industrialisasi abalon di Indonesia. Untuk menjawab tantangan tersebut, maka akan dilakukan penelitian yang bertujan untuk melakukan kajian model pertumbuhan populasi abalon di Pulau Lombok dan mendapatkan kondisi optimum dari kombinasi pemanenan abalon yang diterapkan pada golongan umur yang berbeda-beda. Untuk Pulau Lombok, lokasi budidaya abalon berpusat di Balai Budidaya Laut Pantai Kuta, Lombok Tengah dan Balai Budidaya Laut Pantai Sekotong, Lombok Barat. Rancangan penelitian untuk tahun pertama dimulai dengan menganalisis populasi abalon berdasarkan kelompok umur dan data jumlah populasi betina ke lokasi budidaya abalon secara kontinu. Data yang diperoleh kemudian diolah sehingga didapatkan angka daya tahan hidup (survival rate) tiap kelompok usia abalon menuju tahap usia selanjutnya serta Angka kelahiran (age birth) untuk tiap kelompok usia abalon hasil pemetaan lokasi budidaya abalon di Pulau Lombok. Pengkonstruksian matriks Leslie didasarkan pada angka daya tahan hidup dan angka kelahiran yang telah didapatkan. Dengan analisis software Matlab diperoleh nilai eigen dari matiks Leslie tersebut dan diketahui akar Perronnya. Sehingga model Leslie dari pertumbuhan populasi abalon di Pulau Lombok dapat diketahui. Hasilnya adalah diperoleh model Leslie $X^{k}=0,992 X^{(k-1)}$ yang berarti bahwa bahwa pertumbuhan populasi abalon akan terus menurun dengan akar Perron sebesar 0,992, artinya pertumbuhan populasi abalon di Pulau Lombok akan menurun tiap tahunnya sebesar $0,8 \%$.
\end{abstract}

Kata kunci : Matriks Leslie, Abalon (Haliotis asinina), Pulau Lombok 


\section{BAB I. PENDAHULUAN}

Abalon (Haliotis asinina) merupakan salah satu etnofauna andalan NTB dan nasional sebagai komoditas perairan laut untuk ekspor. Keberadaan siput ini telah memberikan peranan yang penting bagi perekonomian masyarakat pesisir tidak hanya untuk dimakan atau dijual di pasar lokal, tapi juga diekspor ke beberapa negara Asia, Eropa dan Amerika Serikat (Sarkono et al., 2010). Menurut Faturrahman et al (2013), selama ini penangkapan abalon di alam dilakukan secara berlebihan (overexploitation) dan bersifat tidak selektif sehingga menimbulkan penurunan populasinya secara drastis sehingga dapat mengancam kelestarian abalon. Hingga kini pengembangan budidaya abalon secara luas dalam skala industri masih terkendala oleh rendahnya ketersediaan benih dan pertumbuhan abalone yang lambat.

Total produksi abalon dunia dari hasil budidaya dan tangkapan terus meningkat dari 20,370 tahun 2007 menjadi 44, 510 tahun 2008, sementara hasil tangkapan dari alam cenderung terus menurun dari 20,000 ton pada tahun 1970 menjadi 9,000 ton tahun 2008 (Gordon and Cook, 2010) seperti yang tersaji dalam Gambar 1 berikut.

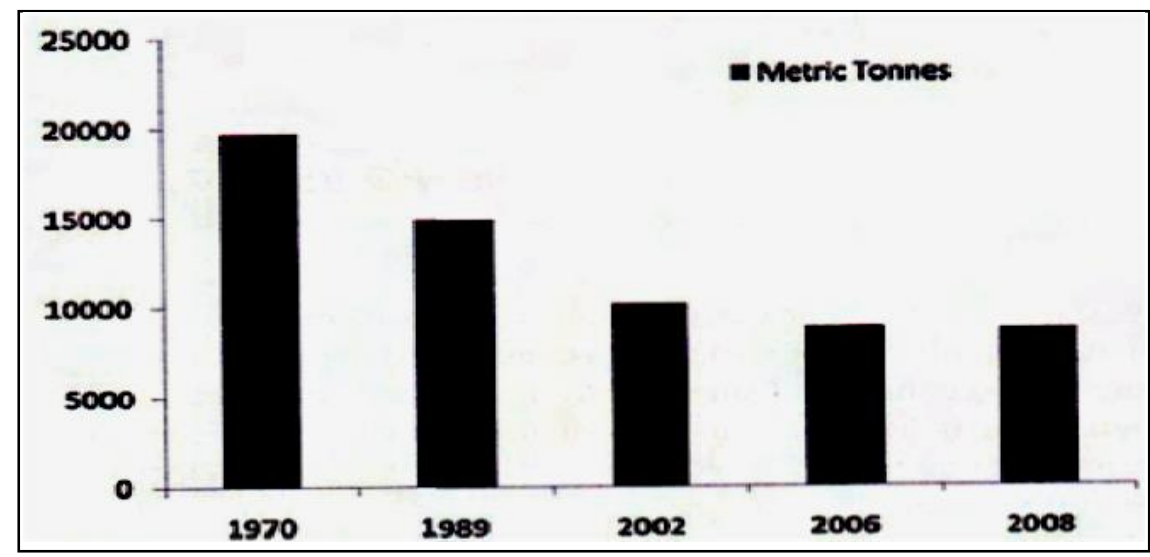

Gambar 1. Produksi abalon dunia dari hasil tangkapan

Menurut ACIAR (2007), ekspor abalon Indonesia yang diwakili oleh NTB ke Hongkong pada tahun 2005 ialah sebesar 5.2 ton dan 3.6 ton pada tahun 2006. Penurunan produksi abalon harian dari hasil tangkapan terlihat dari jumlah produksi pada tahun 1980-an yaitu $300 \mathrm{~kg}$ per hari yang turun menjadi $200 \mathrm{~kg}$ per 
hari di tahun 1990-an dan kurang dari $100 \mathrm{~kg}$ sejak tahun 2000. Selain itu menurut Setyono DED (2008) dalam Faturrahman (2012) juga telah meneliti tentang ukuran panjang cangkang abalon yang turun, dari $8 \mathrm{~cm}$ pada tahun 1980-an menjadi $7 \mathrm{~cm}$ tahun 1990-an dan $\leq 6 \mathrm{~cm}$ sejak tahun 2000 .

Penurunan produksi abalon yang disertai dengan mahalnya harga jual (US $\$ 150 / \mathrm{kg}$ ) dan tingginya permintaan dunia (gap $40 \%$ antara permintaan dan penawaran) tehadap abalon menjadi peluang sekaligus tantangan bagi pengembangan industrialisasi abalon di Indonesia (Faturrahman, 2012). Untuk menjawab tantangan ini, Catton et al (2013) melaporkan bahwa suatu model matriks digunakan untuk menilai potensi pemulihan populasi abalon dengan memasukkan parameter fekunditas, jarak tetangga terdekat, ukuran agregat, rasio jenis kelamin, dan ukuran data frekuensi, yang bertujuan untuk mengevaluasi pengaruh parameter-parameter tersebut pada laju pertumbuhan populasi abalon.

Rogers-Bennet et al (2006) juga telah meneliti model matriks abalone merah, Haliotis rufescens, dan abalone putih, di mana ukuran pertumbuhan populasinya dipengaruhi oleh suatu nilai eigen yang paling dominan. Hal ini senada dengan hasil penelitian oleh tim pengusul yang menyatakan bahwa suatu matriks Leslie dapat memodelkan pertumbuhan sapi di NTB dengan memperhatikan nilai eigen yang paling dominan (akar Perron) (Prayanti et al, 2010). Begitu pula dengan hasil yang diperoleh oleh Romdhini et al (2013), bahwa pertumbuhan penduduk di Kota Mataram dapat dimodelkan dengan matriks Leslie.

Urgensi (keutamaan) penelitian adalah peningkatan produksi budidaya abalon yang dapat meningkatkan pendapatan nelayan dan diharapkan dapat bermanfaat secara luas bagi pengembangan ekonomi. Selain itu, pengembangan teknologi pemanfaatan air yang lebih efisien memiliki strategi jangka panjang untuk meningkatkan pendapatan masyarakat di Pulau Lombok khususnya.

Oleh karena itu pada kajian ini, penerapan matriks Leslie yang diharapkan dapat mengkaji model pertumbuhan populasi abalon di Pulau Lombok dalam rangka meningkatkan produksi abalon dan diperoleh kondisi optimum dari kombinasi pemanenan abalon yang diterapkan pada golongan umur yang berbedabeda. Untuk Pulau Lombok, lokasi budidaya abalon berpusat di Balai Budidaya 
Laut Pantai Kuta, Lombok Tengah dan Balai Budidaya Laut Pantai Sekotong, Lombok Barat. Kedua lokasi inilah yang akan menjadi pusat penelitian tim pengusul untuk memperoleh data data penelitian, seperti yang tersaji pada Gambar 2 berikut.

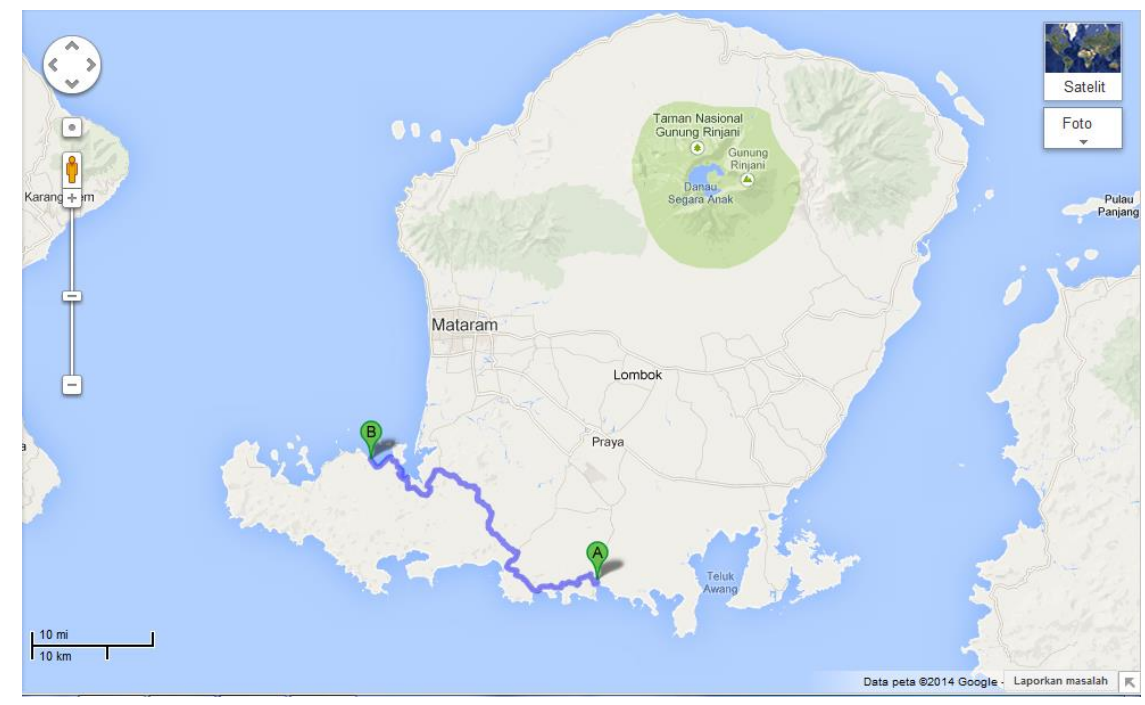

Gambar 2. Peta Lokasi budidaya abalon di Pulau Lombok :

A. Balai Budidaya Laut Pantai Kuta, Lombok Tengah;

B. Balai Budidaya Laut Pantai Sekotong, Lombok Barat.

Adapun tujuan penelitian ini untuk tahun pertama adalah melakukan kajian model pertumbuhan populasi abalon di Pulau Lombok. Sedangkan tujuan penelitian untuk tahun kedua yaitu mendapatkan kondisi optimum dari kombinasi pemanenan abalon yang diterapkan pada golongan umur yang berbeda-beda. 


\section{BAB 2. TINJAUAN PUSTAKA}

Salah satu model pertumbuhan populasi yang sering digunakan oleh ahli demografi adalah Matriks Leslie atau yang biasa disebut dengan model Leslie. Suatu populasi dapat dimodelkan dengan Matriks Leslie dengan mengetahui jumlah populasi perempuan. Setiap saat, komposisi jumlah perempuan dalam suatu populasi dipengaruhi oleh tiga faktor yaitu faktor kelahiran, kematian dan pertambahan usia.

Pada matriks Leslie, untuk mengetahui model pertumbuhan suatu populasi ada beberapa asumsi yang harus terpenuhi yaitu:

1. Hanya dibutuhkan jumlah populasi female (perempuan).

2. Usia maksimum yang dapat dicapai suatu populasi.

3. Kelompok usia dari populasi.

4. Daya tahan hidup (survival rate) tiap kelompok usia menuju tahap usia selanjutnya diketahui.

5. Angka kelahiran (age birth) untuk tiap kelompok usia diketahui

(Yokoyama, 1997).

Para perempuan didistribusikan kedalam beberapa kelompok usia. Misalkan $U$ adalah usia maksimum yang dapat dicapai oleh perempuan pada suatu populasi. Apabila perempuan tersebut dibagi menjadi ke dalam $n$ kelompok berdasarkan usia, maka jarak interval masing-masing kelompok adalah $U / n$. Dengan demikian, kelompok 1 adalah mereka yang berusia $[0, U / n)$, kelompok 2 adalah mereka yang berusia $[U / n, 2 U / n), \ldots$, kelompok $n$ adalah mereka yang berusia $[(n-1) / U, U]$.

Misalkan $t_{i}$ adalah waktu pengamatan, $i=0,1,2, \ldots, k, \ldots$. Pada Model Leslie jarak pengamatan $t_{i-1}$ ke $t_{i}$ sama dengan jarak interval kelompok. Jadi, $t_{i}$ $=i U / n$, untuk $i=0,1,2, \ldots$.

Misalkan $a_{i}$ adalah rata-rata banyaknya anak perempuan yang lahir dari setiap kelompok $i$ dan $b_{i}$ adalah perbandingan antara banyak perempuan yang bertahan hidup (survival rate) sehingga mampu masuk ke dalam kelompok +1 , dengan banyaknya perempuan dalam kelompok $i$. Perhatikan bahwa paling sedikit satu $a_{i} \geq 0, i=1,2,3, \ldots, n$ dan $0<b_{i} \leq 1$. Perhatikan juga paling sedikit satu $a_{i}>$ 
0 , karena jika tidak berarti proses kelahiran tidak terjadi dan $b_{i}>0$, karena jika tidak maka tidak ada perempuan yang dapat bertahan ke dalam kelompok $i+1$.

Misalkan $X_{i}^{(k)}$ adalah banyaknya perempuan pada kelompok $i$ pada pengamatan $t_{k}$ untuk $i=1,2,3, \ldots, n$. Pada saat pengamatan $t_{k}$ banyaknya perempuan pada kelompok 1 sama dengan banyaknya anak perempuan yang lahir di kelompok 1 dari waktu $t_{k-1}$ ke $t_{k}+$ banyaknya anak perempuan yang lahir di kelompok 2 dari waktu $t_{k-1}$ ke $t_{k}+$ banyaknya anak perempuan yang lahir di kelompok $n$ dari waktu $t_{k-1}$ ke $t_{k}$. Jadi,

$$
X_{1}^{k}=a_{1} X_{1}^{k-1}+a_{2} X_{2}^{k-1}+\cdots+a_{n} X_{n}^{k-1}
$$

Karena jarak interval setiap kelompok sama dengan jarak dua pengamatan yang berurutan, maka semua perempuan yang berada pada kelompok $i+1$ pada saat pengamatan $t_{k+1}$ berada pada kelompok $i$ pada saat pengamatan $t_{k}$. Oleh karena itu banyaknya perempuan pada kelompok $i+1, i=1,2, \ldots, n-1$, pada saat pengamatan $t_{k}$ sama dengan banyaknya perempuan yang masih hidup pada kelompok $i$ pada waktu $t_{k-1}$ ke $t_{k}$. Jadi,

$$
\begin{aligned}
& X_{1}^{k}=a_{1} X_{1}^{k-1}+a_{2} X_{2}^{k-1}+\cdots+a_{n} X_{n}^{k-1} \\
& X_{2}^{k}=b_{1} X_{1}^{k-1} \\
& X_{3}^{k}=b_{2} X_{2}^{k-1} \\
& \vdots \\
& X_{i+1}^{k}=b_{i} X_{i}^{k-1}, i=1,2,3, \ldots, n-1
\end{aligned}
$$

Persamaan (2.1) dan (2.2) dapat ditulis dalam bentuk matriks

$$
\begin{gathered}
X^{k}=L X^{(k-1)}, k=1,2,3, \ldots \\
\leftrightarrow\left[\begin{array}{c}
X_{1}^{k} \\
X_{2}^{k} \\
X_{3}^{k} \\
\vdots \\
X_{n}^{k}
\end{array}\right]=\left[\begin{array}{cccccc}
a_{1} & a_{2} & a_{3} & \cdots & a_{n-1} & a_{n} \\
b_{1} & 0 & 0 & \cdots & 0 & 0 \\
0 & b_{2} & 0 & \cdots & 0 & 0 \\
\vdots & \vdots & \vdots & \cdots & \vdots & \vdots \\
0 & 0 & 0 & \cdots & b_{n} & 0
\end{array}\right]\left[\begin{array}{c}
X_{1}^{k-1} \\
X_{2}^{k-1} \\
X_{3}^{k-1} \\
\vdots \\
X_{n}^{k-1}
\end{array}\right],
\end{gathered}
$$


di mana $X^{k}=\left[\begin{array}{c}X_{1}^{k} \\ X_{2}^{k} \\ \vdots \\ X_{n}^{k}\end{array}\right]$, adalah vektor distribusi usia pada waktu $t_{k}$ dan $X^{(k-1)}=$ $\left[\begin{array}{c}X_{1}^{k-1} \\ X_{2}^{k-1} \\ X_{3}^{k-1} \\ \vdots \\ X_{n}^{k-1}\end{array}\right]$ adalah vektor distribusi usia pada waktu $t_{k-1}$, serta $L=$ $\left[\begin{array}{ccccrc}a_{1} & a_{2} & a_{3} & \cdots & a_{n-1} & a_{n} \\ b_{1} & 0 & 0 & \cdots & 0 & 0 \\ 0 & b_{2} & 0 & \cdots & 0 & 0 \\ \vdots & \vdots & \vdots & \cdots & \vdots & \vdots \\ 0 & 0 & 0 & \cdots & b_{n} & 0\end{array}\right]$ disebut matriks Leslie. (Simanihuruk, 2005)

Selanjutnya, untuk memperoleh model pertumbuhan populasi dari matriks Leslie, diperlukan nilai akar Perron. Studi pendahuluan tentang model Leslie yaitu menentukan Hubungan antara model Leslie dengan akar Perronnya telah dibahas dalam Prayanti et al (2010) yang menyatakan bahwa jika $\lambda_{1}$ adalah akar Perron dari Matriks Leslie (L), maka $X^{k}=L X^{(k-1)}$ dapat diwakili oleh $X^{k}=\lambda_{1} X^{(k-1)}$. Model ini diterapkan pada pada populasi sapi di NTB dengan model Leslienya adalah

$$
X^{k}=\left[\begin{array}{ccc}
0 & 0 & 0,35454 \\
1,00351 & 0 & 0 \\
0 & 3,32127 & 0
\end{array}\right] X^{(k-1)}
$$

Akar Perron dari Matriks Leslie untuk Provinsi NTB adalah $\lambda_{p}=1,0572$, karena matriks Leslie dapat diwakili oleh akar Perronnya maka model pertumbuhan sapi di Provinsi NTB berdasarkan akar Perron adalah $X^{k}=$ $1,0572 X^{(k-1)}$. Artinya pertumbuhan pertumbuhan sapi di Provinsi NTB akan meningkat sebesar $5,72 \%$ tiap tahunnya.

Begitu pula dalam Romdhini et al (2013) diperoleh bahwa pertumbuhan populasi penduduk di Kota Mataram dapat dimodelkan dengan matriks Leslie yaitu $X^{k}=1,0303 X^{(k-1)}$, artinya pertumbuhan penduduk di kota mataram tiap tahunnya sebesar 3,03\%. Hal ini berarti target BKKBN pusat yang menargetkan proyeksi pertumbuhan NTB hingga 5 tahun ke depan konstan di angka 2 persen tidak dapat tercapai menurut Matriks Leslie. 
Penerapan matriks Leslie untuk penelitian ini adalah pada populasi abalon di Pulau Lombok. Menurut Faturrahman et al (2013), sistem Budidaya Abalon sampai sejauh ini di Indonesia hanya menggunakan 2 metode yaitu kurungan tancap (Pen-Culture) dan keramba jaring apung (KJA) (Gambar 3).

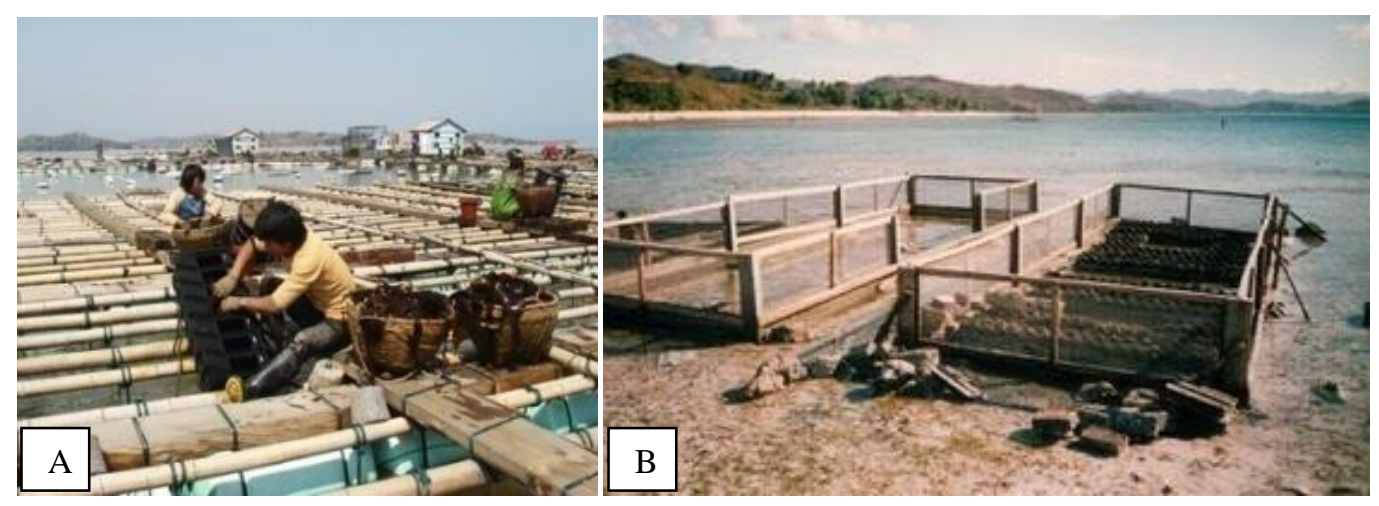

Gambar 3. Beberapa metode budidaya abalone. A. KJA; B. kurungan tancap;

Persyaratan lokasi untuk budidaya abalone dengan metode kurungan tancap adalah daerah pantai dengan curah hujan rendah, jauh/tidak ada muara sungai, pantai yang landai/datar (tidak curam/terjal), dasar pantai pasir berkarang dan terdapat alga laut yang tumbuh, ketinggian air saat surut terendah minimal 10 cm, mudah dijangkau dan diawasi, dan gelombang yang tidak terlalu besar. Metode kurung tancap memiliki beberapa kelemahan diantaranya adalah risiko keamanan yang tinggi baik dari terjangan ombak, predator alami maupun dari gangguan manusia.

Pemilihan lokasi budidaya kerang abalone dengan metode KJA pada prinsipnya sama dengan pemilihan lokasi pada budidaya ikan kerapu bebek (Cromileptes altivelis) dengan sistim KJA. Oleh karena itu, budidaya kerang abalone dapat dilakukan secara bersama dengan ikan kerapu bebek dalam jaring yang berbeda ataupun terpisah. Adapun persyaratan lokasi adalah a) terhindar dari gangguan alam seperti gelombang, arus, bukan daerah up welling, kedalaman peraiaran pada surut terendah minimal 3 meter, dan tidak tercemar, b) faktor kualitas air, seperti salinitas, $\mathrm{pH}$, suhu, DO, ammonia, dan kecerahan.

Nusa Tenggara Barat memiliki banyak daerah pantai yang memenuhi semua kriteria diatas, sehingga berpotensi dijadikan sebagai kawasan pengembangan budidaya abalone nasional. Hampir semua teluk dan gili didaerah 
selatan Lombok Tengah dan Lombok Timur secara bioekologi layak dikembangkan sebagai kawasan budidaya. (Faturahman et al, 2013)

Abalon dikelompokkan dalam kelas gastropoda laut atau siput laut yang memiliki cangkang tunggal. Sebutan abalon berasal dari bahasa spanyol "aulon" atau "aulone." Abalon di Indonesia dikenal dengan sebutan 'siput lapar kenyang' dan 'siput mata tujuh' (Setyono, 2009). Di Indonesia diketahui ada 7 jenis abalon (Dharma, 1988). Ketujuh jenis aballon tersebut yaitu : Haliotis asinina, Haliotis varia, Haliotis squamata, Haliotis ovina, Haliotis glabra, Haliotis planata, dan Haliotis crebrisculpta.

Sebagaimana umumnya terdapat pada siput, abalon memiliki cangkang tunggal dan berada di bagian dorsal serta hampir menutupi semua bagian tubuh abalon. Cangkang abalon multi warna, dan semua warna-warna tersebut ditentukan oleh faktor genetik. Cangkang memiliki deretan lubang yang berfungsi sebagai alat respirasi, pengeluaran urin dan gamet. Cangkang abalon tumbuh melalui penambahan material baru pada bagian anterior dan merupakan salah satu cara yang paling umum digunakan sebagai indikator dari ukuran abalon serta bervariasi antara satu spesies dengan spesies lainnya (Fallu 1991).

Abalon merupakan siput laut yang bergerak dengan kaki perut, kaki inilah yang memiliki nilai komersial sebagai makanan. Cangkang tipis dan rata pada bagian puncak berbentuk spiral seperti telinga. Pada bagian dalam cangkang berwarna putih mengkilap seperti perak dengan sederet lubang-lubang. Seratus tentakel muncul dari tepi sisi kerang dan diduga sebagai alat sensor. Abalon memiliki kepala dengan mata, tentakel dan sebuah radula serta tidak memiliki operculum. Bentuk tubuh asimetrik. Alat gerak terdapat pada bagian ventral, digunakan untu bergerak (Geiger, 2005).

Abalon adalah hewan dioecious (kelamin terpisah), kelenjar reproduksi atau gonad menyelibungi saluran usus dan secara bersama sama membentuk sebuah kerucut diantara otot kaki dan cangkang. Warna gonad mengindikasikan jenis kelamin abalon, induk betina dewasa mempunyai telur berwarna biru, hijau atau coklat dan induk jantan mempunyai gonad berwarna krem, gading, atau putih tulang. Pemijahan merupakan proses pelepasan telur dan sperma. Fertilisasi terjadi secara eksternal,dimana telur dan sperma bertemu dan melebur di kolom air, dan 
telur yang telah terbuahi akan membelah dengan cepat serta membentuk larva/trochopore dan selanjutnya berubah menjadi fase veliger yang memperlihatkan bentuk menyerupai individu dewasa, dimana mata, tentakel dan kaki mulai berkembang. Sebelum fase veliger selesai, larva abalone akan mengalami sebuah proses yang disebut pemilinan (torsi). Fase larva selesai ketika abalone berhenti melayang dan mengendap di dasar. Pada keadaan ini, abalon mulai terlihat seperti replica individu dewasa ( Fallu,1991).

Pertumbuhan merupakan pertambahan ukuran panjang maupun berat suatu individu dalam rentang waktu tertentu (Effendi, 1979). Pertumbuhan abalon tropis, seperti Haliotis asinina, membutuhkan waktu satu tahun untuk mencapai ukuran siap jual (panjang cangkang /shell length/SL 50-60 mm) dari fase embrio. Haliotis asinina yang sudah dewasa dan matang gonad, memiliki panjang cangkang 35-40 mm dengan usia kurang dari satu tahun (Setyono, 2009).

Pertumbuhan Abalon sangat dipengaruhi oleh berbagai faktor seperti kualitas pakan, padat penebaran, dan kualitas air pada saat pembudidayaan. Berikut akan dijelaskan faktor-faktor yang berpengaruh terhadap pertumbuhan Abalon :

1. Kualitas pakan. Pakan yang biasa digunakan dalam budidaya abalon di Indonesia adalah rumput laut jenis Gracilaria. Abalon memakan algae sebanyak 10-30\% dari berat tubuhnya perhari (Hahn, 1989) dalam Setyono (2009).

2. Kualitas air. Penurunan kualitas air yang diakibatkan oleh peningkatan sisa metabolisme, penurunan oksigen terlarut (DO), dan pertumbuhan bakteri, dapat menghambat pertumbuhan juvenil abalon. (Setyono, 2005).

3. Suhu. Abalon memiliki kisaran suhu tertentu untuk dapat tumbuh dan beraktivitas. Suhu optimal untuk pertumbuhan abalon berkisar antara 24$34^{\circ} \mathrm{C}$. Penurunan ataupun peningkatan suhu yang tajam menyebabkan abalon menjadi stres (Susanto, dkk., 2010).

4. Salinitas. Kisaran salinitas untuk abalon dapat tetap hidup dan tumbuh optimal yaitu 22,5-32.5\%. Salinitas dibawah $22.5 \%$ dapat mengakibatkab penurunan pada laju pertumbuhan. Salinitas diatas $35 \%$ mengakibatkan pertumbuhan abalon menjadi tidak optimal, meskipun abalon dapat 
menoleransi salinitas sampai dengan $37 \%$. Penurunan atau peningkatan salinitas yang tajam dapat mengakibatkan abalon menjadi stres (Susanto, dkk., 2010).

5. Kadar oksigen. Kadar oksigen terlarut (Dissolved Oxygen/DO) perairan yang dibutuhkan abalon diperkirakan sebesar 6,25-8,90 ppm. Konsentrasi oksigen terlarut sebesar 4,6-5,7 ppm masih dalam ambang toleransi juvenil abalon. Konsentrasi oksigen terlarut untuk mendukung kehidupan abalon sebaiknya tidak kurang dari 4 ppm (Setyono, 2010).

6. Tingkat keasaman $(\mathrm{pH})$. Abalon dapat hidup optimum dalam kisaran $\mathrm{pH}$ dan kadar amonia tertentu. Kisaran $\mathrm{pH}$ air laut optimum untuk kelangsungan hidup abalon sebesar 7.83-7.85. Kadar amonia untuk pertumbuhan abalon yaitu kurang dari $0.5 \mathrm{ppm}$. Kadar amonia di atas $0.5 \mathrm{ppm}$ tidak dapat ditoleransi oleh juvenil abalon (Burke, dkk. 2001).

7. Padat Penebaran. Penggunaan padat penebaran yang tinggi dapat meningkatkan keuntungan yang lebih besar dalam usaha budidaya akuakultur, termasuk budidaya abalon. Padat penebaran yang tinggi akan menghasilkan banyak abalon dalam waktu yang singkat (Lloyd dan Bates 2008). Padat penebaran yang tinggi memiliki dampak yang langsung dan tidak langsung terhadap pertumbuhan juvenil abalon. Dampak langsung pengaruh padat penebaran terhadap pertumbuhan yaitu kompetisi intraspesifik untuk memperebutkan pakan dan ruang. Abalon butuh ruang gerak yang cukup untuk mengambil makanan. Keterbatasan ruang gerak dalam mengambil makanan juga menimbulkan kesulitan dalam memakan, sehingga berpengaruh terhadap pertumbuhan ablon (Huchette, dkk., 2003; Lloyd dan Bates, 2008). Dampak tidak langsung terhadap pertumbuhan yaitu melelui degradasi kualitas air yang diakibatkan oleh peningkatan akumulasi sisa metabolisme, proliferasi bakteri patogen, dan penurunan DO. Sisa metabolisme, seperti feses, mengandung amonia ataupun sneyawa nitrogen. Senyawa tersebut bersifat racun serta penyebab setres bagi abalon budidaya, sehingga dapat memengaruhi pertumbuhan abalon ( Huchette, dkk. 2003; Lloyd dan Bates 2008). 


\section{BAB 3. METODE PENELITIAN}

Penelitian ini dilaksanakan di lahan budidaya abalon di Pulau Lombok yang berpusat di Balai Budidaya Laut Pantai Kuta, Lombok Tengah dan Balai Budidaya Laut Pantai Sekotong, Lombok Barat. Rancangan penelitian untuk tahun pertama dimulai dengan menganalisis populasi abalon berdasarkan kelompok umur dan data jumlah populasi betina ke lokasi budidaya abalon secara kontinu. Data yang diperoleh kemudian diolah sehingga didapatkan angka daya tahan hidup (survival rate) tiap kelompok usia abalon menuju tahap usia selanjutnya serta Angka kelahiran (age birth) untuk tiap kelompok usia abalon hasil pemetaan lokasi budidaya abalon di Pulau Lombok. Pengkonstruksian matriks Leslie didasarkan pada angka daya tahan hidup dan angka kelahiran yang telah didapatkan. Dengan analisis software Matlab diperoleh nilai eigen dari matiks Leslie tersebut dan diketahui akar Perronnya. Sehingga model Leslie dari pertumbuhan populasi abalon di Pulau Lombok dapat diketahui.

Rancangan penelitian untuk tahun kedua dimulai dengan Menganalisis kebijaksanaan pemanenan abalon secara periodik yang dapat dibenarkan. Dilanjutkan dengan menentukan distribusi umur pada awal periode pertumbuhan dan pada akhir periode pertumbuhan. Selanjutnya mengkonstruksi matriks pemanenan abalon di Pulau Lombok. Hasil dari matris pemanenan tersebut dimodifikasi dengan matriks Leslie yang kemudian ditentukan nilai eigennya berdasarkan analisis software Matlab. Pada akhirnya, hasil nilai eigen ini dapat menentukan banyaknya bagian betina dari tipe kelompok umur yang dipanen di bawah kebijaksanaan panen yang dapat dibenarkan. Tahap akhir adalah menyimpulkan kondisi optimum dari kombinasi pemanenan abalon yang diterapkan pada golongan umur yang berbeda-beda.

Metode penelitian yang dilakukan adalah metode induktif, yaitu dengan mengumpulkan data-data dan referensi-referensi untuk melakukan analisis sehingga diperoleh bentuk umum secara matematis dan dapat ditarik suatu kesimpulan. Hasil penelitian yang diharapkan adalah suatu hasil studi tentang model pertumbuhan populasi abalon di Pulau Lombok sehingga didapatkan 
kondisi optimum dari kombinasi pemanenan abalon yang diterapkan pada golongan umur yang berbeda-beda.

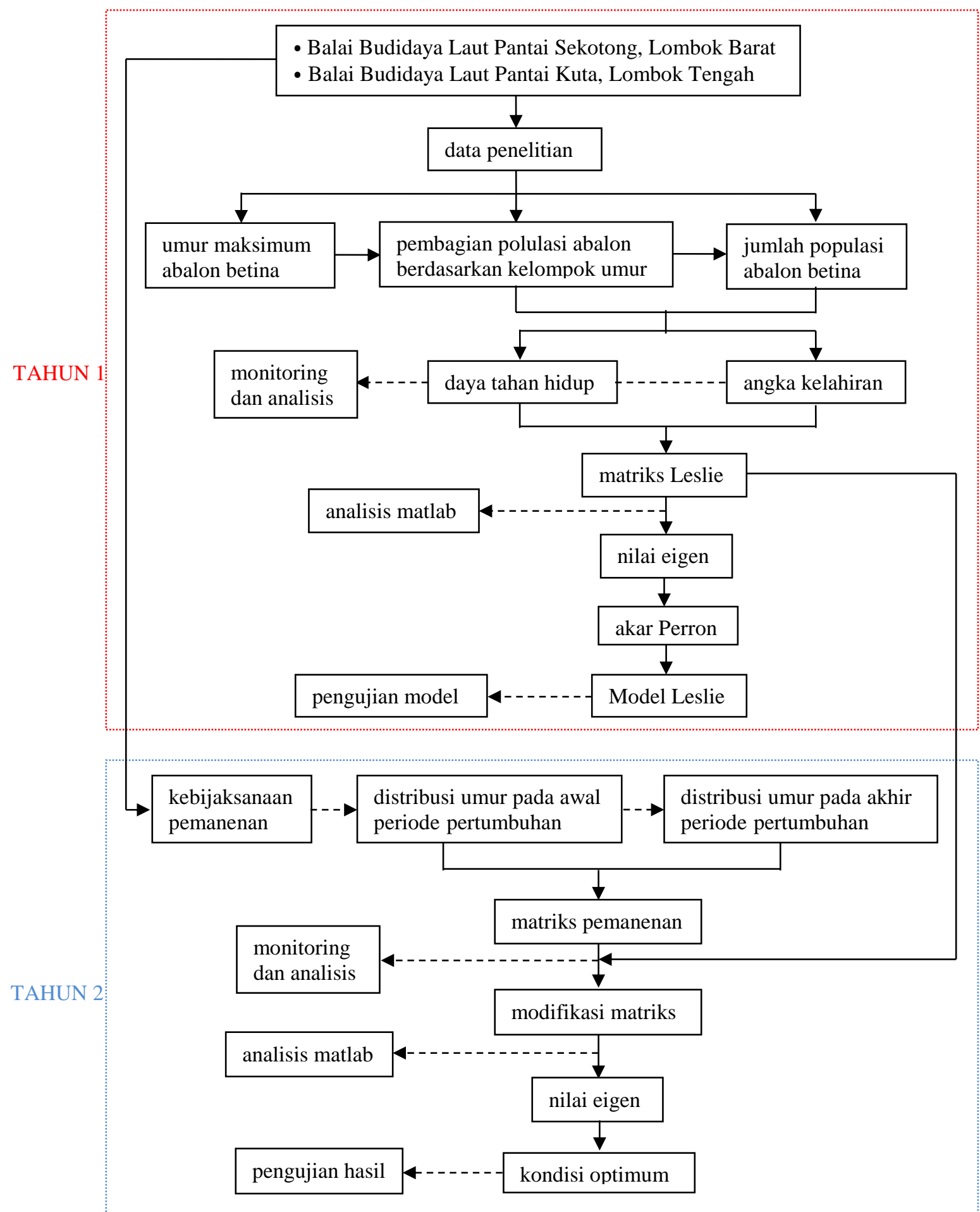

Gambar 4. Metode dan prosedur penelitian 
Hasil penelitian yang diperoleh untuk tahun pertama adalah suatu hasil studi tentang model pertumbuhan populasi abalon di Pulau Lombok, serta kondisi optimum dari kombinasi pemanenan abalon yang diterapkan pada golongan umur yang berbeda-beda untuk hasil tahun kedua tahun kedua. Sedangkan luaran untuk tahun pertama dan kedua yang diharapkan dari hasil penelitian ini adalah publikasi ilmiah pada pertemuan internasional . Luaran ini didukung oleh kegiatan ilmiah tim pengusul yang telah mengikuti Pelatihan Penulisan Artikel Ilmiah Nasional oleh Dikti pada tahun 2012 dan Workshop Penulisan Artikel Internasional pada tahun 2014.

Adapun target atau indikator keberhasilan yang ingin dicapai pada penelitian ini adalah

Bulan ke-4 : - hasil pemetaan lokasi budidaya abalon di Pulau Lombok.

- mengetahui umur maksimum abalon betina dan membagi populasi abalon berdasarkan kelompok umur.

- mengetahui data jumlah populasi betina ke lokasi budidaya abalon secara kontinu.

Bulan ke-6 : - mengetahui angka daya tahan hidup (survival rate) tiap kelompok usia abalon menuju tahap usia selanjutnya serta Angka kelahiran (age birth) untuk tiap kelompok usia abalon hasil pemetaan lokasi budidaya abalon di Pulau Lombok.

- mengetahui matriks Leslie dari pertumbuhan populasi abalon

Bulan ke-9 : - mengetahui nilai eigen dari matriks Leslie pertumbuhan populasi abalon dengan software Matlab.

- mengetahui akar Perron dari Matriks Leslie.

- mengetahui model Leslie sebagai model pertumbuhan populasi abalon di Pulau Lombok berdasarkan akar Perron yang diperoleh.

Bulan ke-12 : - mengetahui model pertumbuhan populasi abalon di Pulau Lombok.

- Artikel ilmiah untuk seminar internasional.

- Laporan akhir tentang model pertumbuhan abalon di Pulau Lombok. 
Bulan ke-15 : - Mengetahui kebijaksanaan pemanenan abalon secara periodik yang dapat dibenarkan

- Mengetahui distribusi umur pada awal periode pertumbuhan

Bulan ke-18 : - Mengetahui distribusi umur pada akhir periode pertumbuhan

- Mengetahui matriks pemanenan abalon

Bulan ke-21 : - Mengetahui hasil modifikasi matriks Leslie dari pertumbuhan populasi abalone pada hasil penelitian tahun pertama dengan matriks pemanenan yang diperoleh

- Mengetahui nilai eigen dari hasil modifikasi matriks Leslie dan matriks pemanenan yang telah diperoleh pada tahap sebelumnya

- Mengetahui banyaknya bagian betina dari tipe kelompok umur yang dipanen di bawah kebijaksanaan panen yang dapat dibenarkan

Bulan Ke-24 : - Menyimpulkan kondisi optimum dari kombinasi pemanenan abalon yang diterapkan pada golongan umur yang berbeda-beda

- Artikel ilmiah untuk seminar internasional.

- Laporan akhir tentang kondisi optimum dari kombinasi pemanenan abalon yang diterapkan pada golongan umur yang berbeda-beda. 


\section{BAB IV. HASIL DAN PEMBAHASAN}

\subsection{Hasil}

Studi kasus berdasarkan data penelitian pertumbuhan benih abalon oleh Setyabudi dan Yana (2014) pada Laporan Kegiatan Perekayasaan Teknologi Budidaya Laut Balai Perikanan dan Budidaya Laut Lombok 2014 dengan judul "Prospek Produksi Benih Hibrid "Ninamata", suatu hasil rekayasa perkawinan abalon Haliotis asinina dan Haliotis squamata" yang dilakukan di Balai Budidaya Laut (BBL) Lombok Desa Gili Genting, Kecamatan Sekotong Barat, Kabupaten Lombok Barat, Provinsi Nusa Tenggara Barat (NTB) selama 8 (dua) bulan. Pada data penelitian tersebut, diperoleh data pertumbuhan panjang dan berat tiga jenis abalon yaitu abalon hibrid, Haliotis asinina dan Haliotis squamata namun yang digunakan pada tugas akhir ini hanyalah data pertumbuhan Haliotis asinina. Wadah pemeliharaan abalon terbuat dari bak beton volume 10 ton. Benih abalon yang dipelihara dengan kepadatan masing-masing 500 ekor/keranjang. Berikut adalah data pertumbuhan panjang cangkang $(\mathrm{cm})$ dan berat (gram) benih abalon tersebut :

Tabel 4.1. Hasil Model Pertumbuhan Abalon Haliotis asinina

\begin{tabular}{|c|r|r|r|r|}
\hline $\begin{array}{c}\text { Umur } \\
\text { (Bulan) }\end{array}$ & $\begin{array}{r}\text { Model } \\
\text { Populasi } \\
\text { (ekor) }\end{array}$ & $\begin{array}{r}\text { Model Berat } \\
(\text { gram) }\end{array}$ & $\begin{array}{r}\text { Model Panjang } \\
(\mathbf{c m})\end{array}$ & $\begin{array}{r}\text { Biomassa } \\
\text { (gram) }\end{array}$ \\
\hline 1 & 391,9630 & 0,02792 & 0,532205 & 10,9418 \\
\hline 2 & 373,4659 & 0,19992 & 1,025848 & 74,6632 \\
\hline 3 & 362,7235 & 0,62281 & 1,498242 & 225,9062 \\
\hline 4 & 355,1001 & 1,37376 & 1,950301 & 487,8229 \\
\hline 5 & 349,1607 & 2,50567 & 2,382901 & 874,8823 \\
\hline 6 & 344,2735 & 4,05161 & 2,796879 & 1394,8610 \\
\hline 7 & 340,1049 & 6,02862 & 3,193037 & 2050,3640 \\
\hline 8 & 336,4574 & 8,44097 & 3,572142 & 2840,0270 \\
\hline 9 & 333,2046 & 11,28279 & 3,934928 & 3759,4780 \\
\hline 10 & 330,2607 & 14,54038 & 4,282097 & 4802,1160 \\
\hline 11 & 327,5649 & 18,19408 & 4,614323 & 5959,7430 \\
\hline 12 & 325,0728 & 22,21982 & 4,932247 & 7223,0600 \\
\hline 13 & 322,7505 & 26,59047 & 5,236486 & 8582,0860 \\
\hline 14 & 320,5719 & 31,27683 & 5,527628 & 10026,4700 \\
\hline
\end{tabular}




\begin{tabular}{|r|r|r|r|r|}
\hline 15 & 318,5166 & 36,24856 & 5,806238 & 11545,7700 \\
\hline 16 & 316,5679 & 41,47486 & 6,072855 & 13129,6100 \\
\hline 17 & 314,7124 & 46,92504 & 6,327995 & 14767,8900 \\
\hline 18 & 312,9389 & 52,56893 & 6,572152 & 16450,8700 \\
\hline 19 & 311,2383 & 58,37727 & 6,8058 & 18169,2400 \\
\hline 20 & 309,6027 & 64,32193 & 7,02939 & 19914,2500 \\
\hline 21 & 308,0255 & 70,37615 & 7,243355 & 21677,6500 \\
\hline 22 & 306,5009 & 76,51461 & 7,448109 & 23451,8000 \\
\hline 23 & 305,0240 & 82,71359 & 7,64405 & 25229,6300 \\
\hline 24 & 303,5906 & 88,95094 & 7,831557 & 27004,6700 \\
\hline
\end{tabular}

(Setyabudi dan Yana, 2014)

Selanjutnya berdasarkan pengambilan data primer ke Balai Perkanan Budidaya Laut Lombok di Sekotong, Lombok Barat, diperoleh data banyaknya abalon berdasarkan panjang cangkangnya, seperti yang tersaji pada Tabel 4.2. berikut

Tabel 4.2 Jumlah populasi abalon di Balai Budidaya Laut sekotong tahun 2015

\begin{tabular}{|c|c|c|}
\hline $\begin{array}{c}\text { Umur Pemeliharaan } \\
(\text { Bulan})\end{array}$ & Panjang $(\mathrm{cm})$ & Jumlah \\
\hline $0-6$ & $0,5-1$ & 1200 \\
\hline $3-6$ & $1-2 \mathrm{~cm}$ & 510 \\
\hline $6-9$ & $2 \mathrm{~cm}$ & 373 \\
\hline $9-12$ & $3 \mathrm{~cm}$ & 133 \\
\hline $12-18$ & $4-5 \mathrm{~cm}$ & 924 \\
\hline $18-24$ & $6-7 \mathrm{~cm}$ & 864 \\
\hline
\end{tabular}

Berdasarkan Tabel 4.2., maka populasi abalone dibagi menjadi 4 kelompok umur, yaitu

Tabel 4.3. Data Banyaknya Abalon Berdasarkan Kelompok Umur Tahun 2015

\begin{tabular}{|l|c|c|c|c|}
\hline & $\begin{array}{l}\text { Kelompok I } \\
(0-6) \text { bulan }\end{array}$ & $\begin{array}{l}\text { Kelompok II } \\
(6-12) \text { bulan }\end{array}$ & $\begin{array}{c}\text { Kelompok III } \\
(12-18) \text { bulan }\end{array}$ & $\begin{array}{c}\text { Kelompok IV } \\
(18-24) \text { bulan }\end{array}$ \\
\hline Banyaknya abalon & 1200 & 1016 & 924 & 720 \\
\hline
\end{tabular}

\subsubsection{Daya Tahan Hidup (Survival Rate)}

Berdasarkan jumlah populasi abalon yang terdiri dari 4 kelompok usia yaitu kelompok I : [0 - 6) bulan, kelompok II : [6-12) bulan, kelompok III : [12 - 18) bulan, kelompok IV : [18-24) bulan, sehingga terdapat 3 angka daya tahan hidup yaitu daya tahan hidup menuju kelompok usia II (SR II), daya tahan hidup menuju kelompok usia III (SR III), dan daya tahan hidup menuju kelompok usia IV (SR IV). Daya tahan hidup 
diperoleh dari perbandingan jumlah abalon pada kelompok $n$ pada tahun ke $t$ dengan jumlah abalon kelompok $n-1$ pada tahun ke $t-1$ dengan rumusan sebagai berikut:

$$
\begin{array}{r}
S R I I=\frac{\sum_{1}^{n}\left(\frac{B_{I I}^{t}}{B_{I}^{t-1}}\right)}{n} \\
S R I I I=\frac{\sum_{1}^{n}\left(\frac{B_{I I I}^{t}}{B_{I I}^{t-1}}\right)}{n} \\
S R I V=\frac{\sum_{1}^{n}\left(\frac{B_{I V}^{t}}{B_{I I I}^{t-1}}\right)}{n}
\end{array}
$$

dimana,

$B_{I}^{t} \quad=$ jumlah populasi abalon usia kelompok I pada tahun $t$

$B_{I}^{t-1}=$ jumlah populasi abalon usia kelompok I pada tahun $t-1$

$B_{I I}^{t} \quad=$ jumlah populasi abalon usia kelompok II pada tahun $t$

$B_{I I}^{t-1}=$ jumlah populasi abalon usia kelompok II pada tahun $t-1$

$B_{I I I}^{t} \quad=$ jumlah populasi abalon usia kelompok III pada tahun $t$

$B_{I I I}^{t-1}=$ jumlah populasi abalon usia kelompok III pada tahun $t-1$

$B_{I V}^{t} \quad=$ jumlah populasi abalon usia kelompok IV pada tahun $t$

$B_{I V}^{t-1}=$ jumlah populasi abalon usia kelompok IV pada tahun $t-1$

[Yokoyama, 1997]

Berdasarkan rumusan di atas, didapatkan daya tahan hidup tiap kelompok usia sebagai berikut

Tabel 2. Angka Daya Tahan Hidup Abalon di Pulau Lombok

\subsubsection{Angka Kelahiran (Age Birth)}

\begin{tabular}{|c|c|}
\hline & Nilai Survival Rate \\
\hline SR II & 0,84666667 \\
\hline SR III & 0,90944882 \\
\hline SR IV & 0,77922078 \\
\hline
\end{tabular}

Angka kelahiran diperoleh dari perbandingan jumlah populasi abalon kelompok usia I pada tahun ke $t$ dengan jumlah populasi abalon kelompok usia IV pada tahun t-1 secara matematika dirumuskan sebagai berikut: 


$$
A B=\frac{\frac{\sum B_{i}^{t-1}}{B_{1}^{t}}}{n}
$$

$\sum B_{i}^{t}=$ Jumlah Dewasa yang produktif

$B_{1}^{t-1}=$ Jumlah Kelas Usia termuda di tahun berikutnya

Sehingga didapatkan angka kelahiran abalon dari induk kelompok usia IV di Pulau Lombok adalah 1,66666667.

\subsubsection{Matriks Leslie dan Akar Perron}

Dari hasil angka kelahiran dan angka daya tahan hidup dapat dimodelkan suatu Matriks Leslie sebagai berikut

$$
L=\left[\begin{array}{cccc}
0 & 0 & 0 & 1,66666667 \\
0,84666667 & 0 & 0 & 0 \\
0 & 0,90944882 & 0 & 0 \\
0 & 0 & 0,77922078 & 0
\end{array}\right]
$$

Dengan menggunakan software matlab diperoleh nilai-nilai eigennya adalah $\lambda_{1}=-0,992 \mathrm{i} \lambda_{2}=0,992, \lambda_{3}=0-992 i, \lambda_{4}=0+992 i$. Sehingga akar perronnya adalah $\lambda_{p}=0,992$. Lebih lanjut, model Leslie dari pertumbuhan populasi abalon di Pulau Lombok dapat dinyatakan dengan persamaan berikut

$$
X^{k}=\left[\begin{array}{cccc}
X^{k}=L X^{(k-1)}, k=1,2,3, \ldots \\
0,84666667 & 0 & 0 & 1,66666667 \\
0 & 0,90944882 & 0 & 0 \\
0 & 0 & 0,77922078 & 0
\end{array}\right] X^{(k-1)}
$$

Selanjutnya sesuai dengan teorema dalam Prayanti (2010), Model Leslie tersebut dapat diwakili oleh akar Perron, yaitu jika $\lambda_{1}$ adalah akar Perron dari Matriks Leslie (L) maka $X^{k}=L X^{(k-1)}$ dapat diwakili oleh $X^{k}=\lambda_{1} X^{(k-1)}$. Sehinga berdasarkan fakta 
tersebut. matriks Leslie $(L)$ di atas dapat diwakili dengan suatu konstanta yaitu akar Perron dari matriks tersebut, sehingga modelnya menjadi

$$
\begin{gathered}
X^{k}=\lambda_{p} X^{(k-1)} \\
\Leftrightarrow X^{k}=0,992 X^{(k-1)}
\end{gathered}
$$

Akar Perron kurang dari 1, ini berarti bahwa pertumbuhan populasi abalon akan terus menurun dengan akar Perron sebesar 0,992, artinya pertumbuhan populasi abalon di Pulau Lombok akan menurun tiap tahunnya sebesar $0,8 \%$. 
BAB V

KESIMPULAN

Matriks Leslie dari pertumbuhan populasi Abalon di Pulau Lombok adalah sebagai berikut

$$
L=\left[\begin{array}{cccc}
0 & 0 & 0 & 1,66666667 \\
0,84666667 & 0 & 0 & 0 \\
0 & 0,90944882 & 0 & 0 \\
0 & 0 & 0,77922078 & 0
\end{array}\right] .
$$

Akar perron dari matriks Leslie tersebut adalah $\lambda_{p}=0,992$. Model Leslie pertumbuhan populasi abalon di Pulau Lombok adalah

$$
X^{k}=0,992 X^{(k-1)}
$$

Akar Perron kurang dari 1, ini berarti bahwa pertumbuhan populasi abalon akan terus menurun dengan akar Perron sebesar 0,992, artinya pertumbuhan populasi abalon di Pulau Lombok akan menurun tiap tahunnya sebesar $0,8 \%$. 


\section{DAFTAR PUSTAKA}

ACIAR (Australian Centre for International Agricultural Research). 2007.

Abalon industry enhancement in eastern Indonesia. Australia

Catton, C.A. \& Rogers-Bennet, L. 2013. Assessing the Recovery of Pink Abalone (Haliotis corrugata) by Incorporating Aggregation into a Matrix Model. Journal of Shellfish Research 32(1):181-187. 2013.

Cook, P.A. \& Gordon H.R. 2010. World abalone supply, market and pricing. Journal of Shellfish Research November 2010 : Vol. 29, Issue 3 (Nov 2010), $\operatorname{pg}(\mathrm{s})$ 569-571

Faturrahman, Immy S.R., Sukiman, dan Ahyadi, H. Strategi Optimalisasi Metode Budidaya Abalon Sebagai Komoditas Unggulan Perikanan Laut. Prosiding Seminar Nasional :Penelitian, Pembelajaran Sains dan Implementasi Kurikulum 2013, Mataram 7 Desember 2013.

Faturrahman. Status terkini abalone di Indonesia. Poster, disampaikan pada Seminar Nasional Peringatan Hari Nusantara. Mataram, Desember 2012.

Fermin, A. C., dan Buen, S. M., 2000, Feeding, growth and survival of abalone (Haliotis asinina Linnaeus 1758) reared at different stocking densities in suspended mesh cages in flow-through tanks. The Philippine Scientist, 37: $31-41$.

Kementerian Kelautan dan Perikanan Direktorat Jenderal Perikanan Budidaya Balai Budidaya Laut Lombok. 2012. Laporan tahunan 2011. Balai Budidaya Laut Lombok : Desa Sekotong Barat, NTB

Kementerian Kelautan dan Perikanan Direktorat Jenderal Perikanan Budidaya Balai Budidaya Laut Lombok. 2013. Laporan tahunan 2012. Balai Budidaya Laut Lombok : Desa Sekotong Barat, NTB.

Kementerian Kelautan dan Perikanan Direktorat Jenderal Perikanan Budidaya Balai Budidaya Laut Lombok. 2014. Laporan tahunan 2013. Balai Budidaya Laut Lombok : Desa Sekotong Barat, NTB.

Kementerian Kelautan dan Perikanan Direktorat Jenderal Perikanan Budidaya Balai Budidaya Laut Lombok. 2015. Laporan tahunan 2014. Balai Budidaya Laut Lombok : Desa Sekotong Barat, NTB.

Minh, dkk.,2010, Growth and Survival of Abalone, Haliotis asinina Linnaeus 1758, Reared in Suspended Plastic Cages, Kasetsart J. (Nat. Sci.). 44 : 621 630.

Prayanti, B.D.A., Romdhini, M.U., dan Wardhana, I.G.A.W. 2010. Economic Policy Analysis of earth a million cows Using Leslie Matrix. Article is 
presented at International seminar on Economic, Culture and Environment, The University of Mataram, Indonesia 11-13 November 2010.

Rogers-Bennett, L. \& R. T. Leaf. 2006. Elasticity analyses of size-based red and white abalone matrix models: management and conservation. Ecol. Appl. 16:213-224.

Romdhini, M.U., Susanto, M., dan Wardhana, I.G.A.W. 2013. Prosiding Seminar Nasional Penelitian, Pembelajaran Sains dan Implementasi Kurikulum Program Pascasarjana Magister Pendidikan IPA, Universitas Mataram 7 Desember 2013

Sarkono, Faturrahman, \& Sofyan, Y. 2010. Isolation and identification of lactic acid bacteria from abalone (Haliotis asinina) as a potential candidate of probiotic. Journal Nusantara Bioscience Vol. 2, No. 1, Pp. 38-42 March 2010 .

Setyabudi dan Yana, 2014, Prospek Produksi Benih Hibrid "Ninamata", suatu hasil rekayasa perkawinan abalon Haliotis asinina dan Haliotis squamata, Laporan Kegiatan Perekayasaan Teknologi Budidaya Laut Balai Perikanan dan Budidaya Laut Lombok 2014, Balai Budidaya Laut (BBL) Lombok, Nusa Tenggara Barat (NTB)

Setyono, D.E.D. 2008. Pertumbuhan dan Mortalitas Juvenil Abalon (Haliotis asinina) di Laboratorium. Jurnal Oseanologi 1(1):35-42.

Setyono, D.E.D. 2009. Abalon: Teknologi Pembenihan. LIPI : Pemenang, Lombok Utara.

Setyono, D.E.D. 2009. Abalon: Biologi dan Reproduksi. LIPI : Pemenang, Lombok Utara.

Simanihiruk, M. 2005. Karakteristik Matriks Leslie Ordo Tiga. Jurnal Gradien Vol.2 NO.1 Januari 2006. hlm. 134-138.

Yokoyama, K. 1997. Population Modeling Using The Leslie Matrix. Prentice Hall, Inc: New Jersey. 